\title{
O zmysłowym doświadczeniu krajobrazu w powieści Roya Jacobsena Oczy z Rigela (2017) ${ }^{1}$
}

\author{
The Sensory Experience of Landscape in the Novel Eyes of the Rigel (2017) \\ by Roy Jacobsen
}

\begin{abstract}
The aim of this paper is to analyse the representation of landscape in the novel Eyes of the Rigel (2017) by the Norwegian writer Roy Jacobsen from the perspective of geopoetics, including literary sensory geography, which accentuates geographical conditions of perception by making use of the findings of geography and anthropology of the senses. The protagonist of the novel lives on a small island off the northern coast of Norway and goes on a journey lasting several weeks, heading towards the south, from the sea through the interior of the country. In Jacobsen's novel, the sensual landscape of the mainland is shaped mainly by auditory, tactile, olfactory, gustatory, and visual experiences, while the home island of the protagonist remains the reference point for these experiences.
\end{abstract}

Keywords: geopoetics, literary sensory geography, Roy Jacobsen, Eyes of the Rigel

\begin{abstract}
Abstrakt: Celem niniejszego artykułu jest analiza reprezentacji krajobrazu w powieści $O c z y$ $z$ Rigela (2017) norweskiego pisarza Roya Jacobsena z perspektywy geopoetyki, w tym literackiej geografii sensorycznej, która akcentuje geograficzne warunki percepcji poprzez wykorzystanie ustaleń geografii i antropologii zmysłów. Bohaterka powieści mieszka na małej wyspie u północnych wybrzeży Norwegii i wyrusza w kilkutygodniową podróż, kierując się na południe, od morza w głąb kraju. W powieści Jacobsena zmysłowy krajobraz stałego lądu kształtują głównie doświadczenia słuchowe, dotykowe, węchowe, smakowe i wizualne, a rodzinna wyspa bohaterki pozostaje dla nich punktem odniesienia.
\end{abstract}

Słowa kluczowe: geopoetyka, literacka geografia sensoryczna, Roy Jacobsen, Oczy z Rigela

${ }^{1}$ Artykuł jest rozbudowaną wersją referatu Wędrówka sensualna w powieści Roya Jacobsena pt. Oczy z Rigela wygłoszonego na II Ogólnopolskiej Konferencji Naukowej „Motyw wędrówki w literaturze i sztuce" (online) w styczniu 2021 roku. 
Przestrzeń geograficzna wzbudza coraz większe zainteresowanie szeroko pojętej humanistyki, z neutralnego tła stając się ,aktywn[ą] sił[ą] warunkując[ą] i kształtując[a] kulturę"2. W takiej roli przestrzeń jest przedmiotem badań między innymi nowej geografii kultury, zapoczątkowanej refleksjami Denisa Cosgrove'a i Petera Jacksona w 1987 roku. O wartości nowej geografii kultury dla badań literackich decyduje przede wszystkim jej otwartość na impulsy z zewnątrz, zarówno w zakresie teorii, jak i praktyk - nie tylko praktyk artystycznych, ale także - w rezultacie przyjęcia przez nową geografię kultury antropologicznej definicji kultury Raymonda Williamsa - tych dotyczących życia codziennego. Co istotne, dla nowej geografii kultury niebagatelne znaczenie mają praktyki interpretacyjne ${ }^{3}$.

Dialog między badaniami literackimi i nową geografią kultury jest szczególnie produktywny w przypadku kategorii krajobrazu ${ }^{4}$. Nowa geografia kultury skupia się na uwarunkowaniach jego postrzegania. Elżbieta Rybicka wyróżnia tu trzy podejścia, które charakteryzuje za pomocą słów kluczy: estetyka, polityka i sensoryka. Mamy zatem do czynienia: po pierwsze, z kulturowym wytwarzaniem krajobrazu z naciskiem na rolę sztuki i ikonografii; po drugie, z krajobrazem jako wytworem ideologicznym; wreszcie po trzecie, z krajobrazem postrzeganym zmysłowo 5 .

To właśnie to trzecie podejście jest teoretycznym punktem wyjścia w niniejszym artykule, którego celem jest analiza reprezentacji krajobrazu w powieści norweskiego autora Roya Jacobsena zatytułowanej Oczy z Rigela z perspektywy geopoetyki, a w jej ramach sensorycznej geografii literackiej, badającej geograficzne uwarunkowania percepcji, z wykorzystaniem zdobyczy geografii zmysłów i antropologii zmysłów 6 .

Oczy z Rigela to jedna z powieści Jacobsena tworzących serię, nazywaną niekiedy „sag[a] rodziny Barrøy”, o losach mieszkańców położonej na słabo zaludnionym północnonorweskim wybrzeżu maleńkiej wyspy Barrøy (od której, jak można zauważyć, pochodzi ich nazwisko). Pierwsza część cyklu, De usynlige, została wydana w Norwegii w 2013 roku i zapewniła autorowi miejsce w finale Nagrody Bookera. Druga, Hvitt hav, ukazała się w 2015. Trzecią, Rigels øyne, opublikowano w 2017 roku, czwartą zaś i jak dotąd ostatnią, Bare en mor, w 2020. W Polsce powieści te ukazują się w tłumaczeniu Iwony Zimnickiej, nakładem Wydawnictwa Poznańskiego, w prestiżowej Serii Dzieł Pisarzy Skandynawskich, która w 2018 roku została wznowiona po prawie trzydziestoletniej przerwie, a otworzyła ją właśnie pierwsza część sagi Jacobsena pod polskim tytułem Niewidzialni. Kolejne tomy ukazywały się błyskawicznie - tom drugi, Białe morze,

${ }^{2}$ E. Rybicka, Literatura, geografia: wspólne terytoria [w:] Od poetyki przestrzeni do geopoetyki, red. E. Konończuk, E. Sidoruk, Białystok 2012, s. 12.

${ }^{3}$ Por. ibid., s. 13-14.

${ }^{4}$ Por. ibid., s. 14.

${ }_{5}^{5}$ Por. ibid., s. 14-16.

${ }^{6}$ Por. E. Rybicka, Geopoetyka. Przestrzeń i miejsce we wspótczesnych teoriach i praktykach literackich, Kraków 2014, s. 247.

${ }^{7}$ Por. Oczy z Rigela, Wydawnictwo Poznańskie, https://wydawnictwopoznanskie.pl/produkt/ oczy-z-rigela/ (dostęp: 27.04.2021). 
w 2019 roku; trzeci, czyli Oczy z Rigela, w 2020, zaś tom 4 Tylko matka ukazał się we wrześniu 2021 roku.

Na główną bohaterkę serii wyrasta Ingrid Marie Barrøy. Trzyletnia na pierwszych stronach Niewidzialnych, przejmuje z czasem rodzinną wyspę w dziedzictwie po dziadku i ojcu. W Białym morzu, podczas drugiej wojny światowej, Ingrid ratuje Aleksandra, rosyjskiego jeńca, rozbitka z katastrofy niemieckiego statku Rigel. Najpierw ukrywa mężczyznę na wyspie, a ostatecznie, dla bezpieczeństwa ich obojga, nakłania do samotnej ucieczki z kraju.

Akcja Oczu z Rigela rozgrywa się latem 1946 roku. Ingrid wyrusza śladem Aleksandra, którego córkę urodziła niespełna rok wcześniej. Oczy dziecka coraz bardziej przypominają Ingrid oczy Rosjanina - co wyjaśnia dosyć zagadkowy tytuł powieści - $\mathrm{i}$ to podobieństwo jest dla głównej bohaterki najważniejszym powodem do podjęcia wędrówki. Nie jest to jednak jedyna motywacja jej decyzjipoznanie prawdy o losach Aleksandra pozwoli także Ingrid na udzielenie sobie samej odpowiedzi na fundamentalne pytanie „Kto ty jesteś?”. Choć pytanie to pada z ust ciotki, zdezorientowanej po wylewie, Ingrid traktuje je z całą powagą. Wyrusza w drogę, gdyż wie, że „będzie musiała odpowiedzieć na to bezsensowne pytanie zgodnie z prawdą, aż po najdrobniejszy szczegół" "Ten wymiar wyprawy jest szczególnie interesujący z perspektywy geopoetyckiej, która nadaje podróży status doniosłego doświadczenia życiowego, etapu w budowaniu tożsamości ${ }^{10}$. Ów wymiar nabiera również istotnego znaczenia w świetle literackiej geografii sensorycznej, zwłaszcza, jeśli uznać podmiotowość za osobny zmysł, rozpoznany - jak przypomina Juhani Pallasmaa - już średniowieczu ${ }^{11}$ :

Nasze zmysły nie są wyłącznie pasywnymi receptorami bodźców; są procesami, które aktywnie i nieustannie rozciągają się, poszukują, egzaminują i kształtują całość świata i nas samych. Nasze zmysły i nasze cielesne bycie są ośrodkami niemej wiedzy i w sposób fundamentalny kształtują bycie-w-świecie. Wszystkie nasze zmysły - podobnie jak nasze bycie - „myślą” w tym sensie, że otrzymują oraz przetwarzają informacje i całkowicie ujmują skomplikowane egzystencjalne wydarzenia. Filozofia średniowieczna zidentyfikowała szósty, unifikujący zmysł, zmysł podmiotowości, poprzez który podmiot rozpoznaje siebie jako siebie ${ }^{12}$.

Narrator nazywa bohaterkę ,istotą związaną z morzem”"13, używa też określenia „Ingrid z morza”" ${ }^{14}$. Surowe środowisko Barrøy, której nazwa w języku norweskim znaczy tyle co ,naga wyspa”, tworzy geograficzne ramy percepcji Ingrid. Rodzinna wyspa, punkt - nomen omen - wyjścia dla wyprawy Ingrid, będzie stałym punktem odniesienia dla jej zmysłowych wrażeń. W ten sposób Barrøy

${ }^{8}$ R. Jacobsen, Oczy z Rigela, przeł. I. Zimnicka, Poznań 2020, s. 8.

9 Ibid.

${ }^{10}$ Por. E. Konończuk, Mapa jako metafora w ,opowieściach przestrzennych” Andrzeja Stasiuka [w:] Od poetyki przestrzeni do geopoetyki, red. E. Konończuk, E. Sidoruk, Białystok 2012, s. 35.

${ }^{11}$ Por. J. Pallasmaa, Krajobrazy zmystów. Dotykanie świata przez architekturę, przeł. M. Choptiany, „Autoportret” 2011, nr 3, s. 6.

12 Ibid., s. 9.

${ }^{13}$ R. Jacobsen, Oczy..., s. 81.

${ }^{14}$ Ibid., s. 124. 
jest w tekście stale obecna, mimo że akcja w przeważającym stopniu toczy się poza nią.

Wyspa zatraca tym samym - co jest dodatkowo interesujące z punktu widzenia geopoetyki - swój charakter miejsca, które za Rybicką można nazwać „wydrążon[ym] z pamięci”"15. Zgłębiając relację między twórczością literacką, miejscem a pamięcią (w większym stopniu zbiorową niż prywatną), badaczka zwraca uwagę na miejsca dotknięte ,erozj[a] pamięci” ${ }^{16}$. Stają się one często źródłem pisarskiej aktywności i tu Rybicka wprowadza rozróżnienie ujęcia kreacyjnego oraz zbliżającego się do dokumentu, bardziej materialnego ${ }^{17}$. Sytuujący się w nurcie kreacyjnym Jacobsen kwestię zbiorowej pamięci czyni centralną nie tylko w Oczach z Rigela, ale także we wszystkich częściach swego cyklu. W Niewidzialnych ustawił akcent na pamięć miejsc, chciał pisać o ,białych plamach w atlasach"18, takich jak powieściowa Barrøy - podobna do tysięcy innych norweskich wysp, tak niewielkich, że ich mieszkańców stanowiła zazwyczaj zaledwie kilkuosobowa rodzina skupiona w jednym lub dwóch budynkach, po których dziś, w najlepszym razie, pozostały jedynie fundamenty ${ }^{19}$. Zainteresowanie Jacobsena zapomnianymi wyspami można widzieć na szerszym tle, między innymi jako rezultat zwrotu przestrzennego w humanistyce, który manifestuje się także przez skierowanie uwagi na miejsca rzadko obecne w literaturze, ,pozbawione potencjału wytwarzanego przez teksty kultury"20.

Pierwszy etap każdej podróży z Barrøy to przeprawa łodzią przez morze do wyspy głównej Hovedøya. Tam, u zaufanych ludzi, którzy udzielili Aleksandrowi pomocy, bohaterka dowiaduje się, jaki miał być kolejny etap jego trasy. W ten sposób, polegając na szczątkowych i nie zawsze pewnych informacjach, uzyskanych od postaci napotkanych w drodze, Ingrid w ciągu kilku letnich tygodni przemierza Norwegię, kierując się z północy na południe, od morskich krańców przez wnętrze kraju.

Poza samolotem wykorzystuje chyba wszystkie dostępne środki lokomocji: łódź, statek transportowy, rower, pociąg, autobus i wóz konny. Przede wszystkim jednak ogromne odległości pokonuje pieszo. Są to w większości takie sposoby podróżowania, które nie separują od środowiska, lecz przeciwnie, oznaczają aktywny w nim udział ${ }^{21}$.

Sensualny krajobraz stałego lądu powstaje w percepcji Ingrid z połączenia wrażeń - przede wszystkim audialnych, taktylnych, olfaktorycznych, gustatorycznych i wizualnych. Bohaterka świadomie nastraja się na zmysłowy odbiór

${ }^{15}$ E. Rybicka, Geopoetyka..., s. 310.

16 Ibid., s. 312.

${ }^{17}$ Por. ibid., s. 313.

${ }_{18}$ M. Bjørnersen, Folk har behov for å glemme det mest pinlige, https://www.boktips.no/ skjonnlitteratur/roy-jacobsen-2/ (dostęp: 27.04.2021). Tłumaczenie moje.

19 Por. ibid.

${ }^{20}$ E. Konończuk, Geobiograficzne doświadczenie lektury [w:] Przestrzenie geo(bio)graficzne w literaturze, red. E. Konończuk, E. Sidoruk, Białystok 2015, s. 68.

${ }^{21}$ Por. M. Roszczynialska, Pótnoc - Poludnie. Geobiografia Michała Olszewskiego [w:] Przestrzenie geo(bio)graficzne w literaturze, red. E. Konończuk, E. Sidoruk, Białystok 2015, s. 192. 
otoczenia - w pewnej sytuacji narrator zaznacza, że Ingrid „usiłuje [...] poczuć”22 okolicę.

W Oczach z Rigela w zmysłowym krajobrazie wnętrza kraju dominują wrażenia słuchowe. Można je dookreślić za pomocą proponowanych przez Tomasza Misiaka terminów sonosfera i fonosfera. Przez sonosferę Misiak rozumie „otaczając[ą], dźwiękow[ą] rzeczywistoś[ć]”23 - termin odnosi się zarówno do „czynności związanych z wydobywaniem dźwięku, jak i do pewnych właściwości samego dźwięku"24. Fonosfera obejmuje zaś ludzką ekspresję głosową ${ }^{25}$. Dźwiękowe znaki rozpoznawcze rodzinnych stron bohaterki związane ze sonosferą to „krzyk mew, plusk morza, spokojne kwakanie edredonów”26. W drodze przez wnętrze kraju Ingrid notuje przede wszystkim nieobecność tych odgłosów. W jednym z oddalonych od morza domostw stwierdza, że „dziwnie się czuje, będąc tutaj, gdzie wszystkie okna są otwarte, a nic nie słychać" 27 . Uderza ją „,brak ptasich krzyków”"28, zwłaszcza tych wydawanych przez znane jej gatunki: „Było tu mało ptaków, za każdym z nich mogła odwrócić głowę i żaden nie był mewą, rybitwą ani kormoranem, szła przez bezgłośne królestwo"29. Brak oswojonych dźwięków jest często w percepcji Ingrid jednoznaczny z ciszą, jakby bohaterka świadomie zamykała swój słuch na nowe wrażenia. Wytłumieniu zewnętrznych odgłosów towarzyszy niekiedy u Ingrid „włączanie” dźwięków rozpoznawczych Barrøy, które narrator nazywa jej „,wewnętrzną orkiestrą"30 ${ }^{30}$ jak podczas krótkiego pobytu bohaterki w miejscowości Røros, w głębi kraju, gdzie Ingrid nie słyszy dźwięków otoczenia, gdyż myślami, albo raczej zmysłami, jest wciąż w domu: „słyszała krzyki mew i wiatr, wewnętrzną orkiestrę w owej nienaturalnej ciszy, która włada żyjącym miastem"31. Z ciszy składa się także krajobraz dźwiękowy Trondheim, po którym bohaterka spaceruje ,nie dopuszczając do siebie dźwięków"32. Jednak Ingrid nie zamyka się zupełnie na nowe odgłosy. Pewnego ranka budzi ją ,śpiew ptaków, jakiego [...] nigdy wcześniej nie słyszała, lecz przyjemnie się go słuchało" 33 , w pewnej okolicy rejestruje, że „owady bzyczą tu inaczej niż na morzu" ${ }^{\prime 3}$, z kolei na jednej z dworcowych poczekalni wychwytuje

22 R. Jacobsen, Oczy ..., s. 105.

${ }^{23}$ T. Misiak, Audiosfera w kulturze wspótczesnej. Próba przybliżenia pojęcia, „Przegląd Kulturoznawczy" 2010, nr 1, s. 65.

${ }^{24}$ Ibid., s. 64.

${ }^{25}$ Por. ibid., s. 65.

${ }^{26}$ R. Jacobsen, Oczy..., s. 13.

27 Ibid., s. 75.

${ }^{28}$ Ibid., s. 58.

${ }^{29}$ Ibid., s. 121.

${ }^{30}$ Ibid., s. 143.

${ }^{31}$ Ibid.

${ }^{32}$ Ibid., s. 243.

${ }^{33}$ Ibid., s. 67.

${ }^{34}$ Ibid., s. 70. 
„więcej dźwięków i echa niż na morzu”35. Niektóre odgłosy ją zaskakują, jak „szemrząc[e] wśród ciszy strumieni[e]”36 czy „las szumiący bez wiatru”37.

Jednym z najbardziej charakterystycznych dźwięków rozpoznawczych stałego lądu jest odgłos lokomotywy. Na maleńkiej wyspie, z której pochodzi Ingrid, nie ma, rzecz jasna, kolei, ale to właśnie kolej bohaterka uznaje, obok telefonu, za element łączący „,wszystkie zakątki kraju”38. W uszach Ingrid nadjeżdżający pociąg wydaje „histeryczny ryk" ${ }^{39}$, słychać go ,Z tak daleka, że ludzkie oko tam nie sięga; jest niczym parskający złością lodochód, otaczają go ryk, zgrzyty i błyski światła [...], wjeżdża $\mathrm{z}$ hukiem i zatrzymuje się z jękiem głośnym jak ten wydobywający się z parującego pogorzeliska" ${ }^{40}$. Odjazd pociągu również nie należy do przyjemnych doświadczeń: „potwór znów mógł zacząć parskać i zabrać grzmot z tej okolicy, zanikający o wiele szybciej niż huk, z którym przybył" ${ }^{\prime 4}$. Te złowrogie dźwięki bohaterka próbuje oswajać, odwołując się do znanych sobie odgłosów - lodochodu i pogorzeliska.

Dźwiękowy krajobraz stałego lądu budują także elementy fonosfery. Ingrid spotyka na swojej drodze postacie posługujące się różnymi dialektami języka norweskiego. Rozmów nie udaje się przeprowadzić bezproblemowo, zwykle muszą padać dodatkowe pytania: „co” i ,jak” w dwóch różnych dialektach”42. Bywają momenty, w których Ingrid z powodu różnic dialektalnych nie wszystko rozumie $^{43}$. Zdarza się także, że rozpoznaje $w$ mowie nieznajomych ich korzenie $\mathrm{w}$ jej rodzinnych stronach ${ }^{44}$. Jest to kolejny impuls do powrotu myślą $\mathrm{w}$ te tereny: „rozmawiali o wspólnych znajomych [...] i zapewne wyobrażali sobie również miejsca, z których pochodzili, Barrøy i wyspę położoną nieco dalej na północy”45.

Bohaterka doświadcza stałego lądu również przez charakterystyczne bodźce dotykowe. Lato jest cieplejsze niż na wyspie, panuje „daleki od morza upał”46. Ingrid odczuwa „suchy lądowy wiatr”47, zwraca uwagę na lekkie chmury, ,jakie potrafią się unosić wyłącznie ponad suchą ziemią"48. Z suchym powietrzem i wnętrzem kraju łączą się jeszcze inne doznania taktylne - ukąszenia owadów oraz odczuwane na całym ciele „kurz i pyłki” ${ }^{49}$. To właśnie obecność kurzu ${ }^{50}$ staje się jedną z najwyraźniejszych cech dystynktywnych niewyspiarskiej Norwegii.

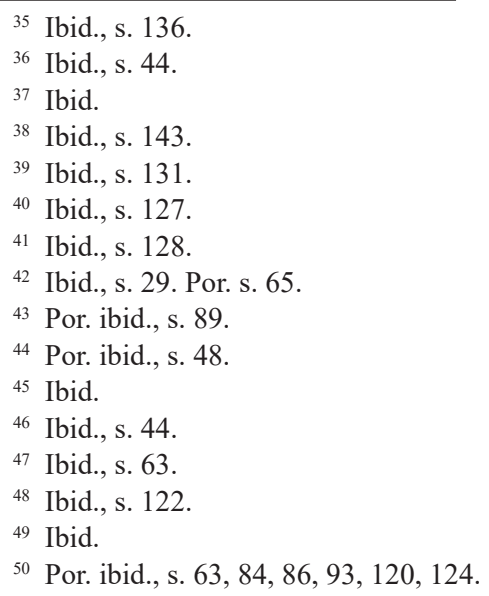


Sensualny krajobraz stałego lądu obejmuje także wrażenia zapachowe. Odwołanie do zmysłu powonienia otwiera i zamyka opis szczegółów urbanistycznych Skorovas, dopiero powstającej górniczej osady. Bohaterka czuje ,zapach białego świeżego drewna, smoły, farby i cementu, zapach miasta dla sześciuset-siedmiuset dusz, ze szkołą, izbą chorych, pocztą, kaplicą, elektrownią, warsztatami, ze stajniami, z pralniami i zakładami produkcyjnymi, zapach narodowego marzenia, które właśnie się spełniało"51. W pociągu, w bliżej nieokreślonym punkcie na mapie kraju, Ingrid rozróżnia wonie, które przypisuje terenom położonym z dala od morza: ,zapach żelaza, kamienia, lasu i kreozotu, zapach wnętrza kraju" 52 .

W doświadczeniu stałego lądu udział ma poza tym zmysł smaku. Nie jest to jednak kwestia kulinarnej specyfiki konkretnych regionów, często podejmowana przez geografię zmysłów ${ }^{53}$. Podczas przeprawy łodzią przez jezioro bohaterkę związaną z morzem pozytywnie zaskakuje doznanie na pozór zwyczajne: „Ingrid wychyliła się przez burtę, zaczerpnęła ręką wody, napiła się i powtórzyła ten ruch. Mariann spytała, co ona wyprawia"54. Mariann pochodzi z głębi lądu i nie pojmuje ,zachwytu słodką wodą, tego, jak bardzo może dziwić przebywanie w łodzi na wodzie, której można się napić" "55. Ingrid przemierza zatem krainę słodkiej wody.

Wnętrze kraju dostarcza również charakterystycznych doznań wzrokowych. Spytana przez jednego ze swoich przewodników o wrażenia, jakie wywiera na niej las, Ingrid „rozejrzała się i stwierdziła, że jej spojrzenie nigdy nie zatrzymywało się tak blisko" "56. Mieszkanka wyspy, przywykła do oddalonego horyzontu, przecinając górskie pasmo, nie dostrzega zmieniającej się wraz z wysokością szaty roślinnej, rejestruje natomiast fakt, że im wyżej wędruje, tym większą przestrzeń może objąć wzrokiem - las ,ze świerkowego zmienił się w sosnowy, a Ingrid tego nie zauważyła, a następnie w brzozy, które stawały się coraz niższe i w końcu przerodziły się w wierzby, jałowce i wrzosy, co już zauważyła, bo im wyżej się wspinała, tym dalej mogło sięgać jej spojrzenie"57. Na stałym lądzie wzrok pokonuje zazwyczaj krótszy dystans do widnokręgu, może za to objąć wiele nowych obiektów. Na ziemi bohaterka dostrzega ,wiele kwiatów, jakich nigdy wcześniej nie widziała" 58 , w powietrzu krążą ,wszystkie te połyskujące owady" ${ }^{2}$, których także „nigdy wcześniej nie widziała" ${ }^{\circ}$, nocą zaś na niebie południowej Norwegii świecą ,gwiazdozbiory" ${ }^{1}$, których Ingrid, jak informuje narrator, również ”nigdy dotąd nie widziała" ${ }^{62}$. Wracając pamięcią na wyspę, bohaterka zauważa też różni-

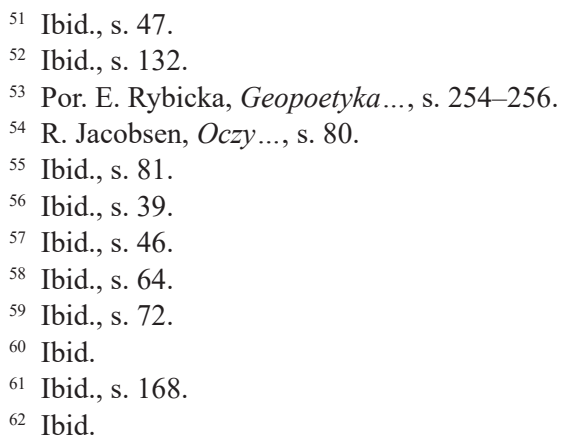


cę w nocnym świetle: „myślała o jasnych nocach na północy, które teraz powoli stawały się już równie ponurymi pustkowiami jak noce tu, na południu"63.

Dla geografii wizualnej interesujące jest nie tylko samo widzenie i akt spojrzenia, ale również różnego rodzaju przybory związane ze zmysłem wzroku ${ }^{64}$. W powieści Jacobsena ich przykładem jest „oprawiona w ramki za szkłem mapa Norwegii"65, wisząca „na następnym dworcu”66, do którego kieruje się Ingrid. W tekście nie pojawia się nazwa miejscowości, w której dworzec ten się znajduje. $\mathrm{Na}$ ochraniającym mapę szkle widnieje w tym punkcie ,szara plama" ${ }^{97}$ powstała od dotyku zaznaczających swoje położenie podróżnych. Mapa nie pełni tu zatem swoich klasycznych funkcji. Narrator nadmienia natomiast, że stojąc przed nią, bohaterka znajduje się „w samym środku kraju i w samym środku lata"68. W sposób specyficzny dla trylogii Jacobsena czas i miejsce akcji pozostają niedoprecyzowane. Większe znaczenie zdaje się mieć wrażenie zanurzenia Ingrid w przestrzeni i czasie, sugerowane przez ostatnie z cytowanych tu sformułowań.

Zarówno rodzinne strony bohaterki, jak i tereny poznawane przez nią podczas wędrówki, są w powieści przedstawiane najczęściej za pomocą opisu polisensorycznego. Elementy takiego ujęcia były już obecne we wcześniej cytowanych fragmentach, jak na przykład we wzmiance o charakterystycznych dla stałego lądu dźwiękach lokomotywy, którym towarzyszą efekty wizualne - „błyski światła”. Krajobraz Barrøy przyjmuje dla Ingrid skondensowaną formę doznań olfaktorycznych i wizualnych - ,poczuła groźny cień tęsknoty za domem, za zapachem morza, za widokiem ludzi i ptaków, zwierząt na łąkach" "70. W drodze powrotnej, stojąc na pokładzie kutra, bohaterka wychwytuje wizualne, audialne i olfaktoryczne wrażenia typowe dla swoich okolic: ,oglądała fiordy, wyspy i znajome kształty gór wznoszących się na horyzoncie przed nimi, słuchała krzyków mew i oddychała morzem" "71. Stały ląd angażuje zmysł dotyku, smaku i słuchu bohaterki w scenie odpoczynku nad rzeką, ,pełną chłodnej, słodkiej wody, ale wydającą z siebie odgłosy morza"72. We wrażenia taktylne i olfaktoryczne obfituje podróż autobusem, na początku której Ingrid zagłębiła się „,w ciężki zapach ludzi zamkniętych w zbyt brutalnym cieple, nabrała tchu i znalazła dla siebie miejsce, klejące się do ud"73. Z kolei od doznań taktylnych i wizualnych rozpoczyna się pewien ,„poranek [który] zakurzył okno, pokrył je żółtym pyłem wnętrza kraju, kładącym się na oczach, szkle, skórze i ubraniu"74.

\footnotetext{
63 Ibid., s. 203.

${ }^{64}$ Por. E. Rybicka, Geopoetyka..., s. 257.

65 R. Jacobsen, Oczy..., s. 197.

66 Ibid.

67 Ibid.

68 Ibid.

69 Ibid., s. 127.

70 Ibid., s. 57.

71 Ibid., s. 245.

72 Ibid., s. 63.

73 Ibid., s. 147.

74 Ibid., s. 157.
} 
Literackiej geografii sensorycznej towarzyszy krytyczny namysł nad hierarchią zmysłów ${ }^{75}$. Ta, której autorstwo tradycja przypisuje Arystotelesowi, wyróżnia ich pięć i porządkuje od wzroku, uznawanego za zmysł najwyższy, przez słuch, węch i smak, po najniższy ze zmysłów - dotyk ${ }^{76}$. Charakterystyczny dla cywilizacji zachodniej wzrokocentryzm ulega jedna stopniowej relatywizacji ${ }^{77}$.

Dyskusyjne może być również ograniczenie liczby zmysłów do pięciu, czego przykład pojawił się już w tym artykule, w związku ze zmysłem podmiotowości. Filozofia Steinerowska wymienia zmysłów dwanaście, zredagowana zaś przez Davida Howesa antologia The Sixth Sense Reader sugeruje, że jest ich trzydzieści trzy ${ }^{78}$.

Zmysł ruchu i zmysł równowagi, wyróżniane przez Rudolfa Steinera ${ }^{79}$, to dwa dodatkowe zmysły, które trudno wpisać w tradycyjną piątkę, a które wydają się istotne dla percepcji krajobrazu w powieści Jacobsena. Przyglądając się bohaterce na początku wyprawy, już na stałym lądzie, narrator czyni ogólną uwagę: „Istnieje wiele sposobów chodzenia" 80 . Następnie informuje, że „Ingrid Marie Barrøy szła lekko w rybackich butach" "\$1. Jej chód jest najczęściej określany właśnie jako lekki ${ }^{82}$, ale dla doświadczenia nowej przestrzeni ważniejsza jest raczej informacja o obuwiu - rybackim, typowym dla wyspiarzy. W innej wzmiance o bohaterce maszerującej w rybackich butach, narrator zauważa, że porusza się ona „niespodziewanie długim krokiem [...] na nogach ma buty z cholewami - wydają się za duże" ${ }^{83}$. Z czasem Ingrid nabywa „obuwie z rodzaju tych, jakie nosili górnicy" ${ }^{\text {. }}$. Czuje, że te „leż[ą] na nogach o wiele lepiej niż rybackie buty z cholewami”" ${ }^{\circ 5}$. Różnice między wyspą i stałym lądem można najwyraźniej odbierać także poprzez zmysł ruchu - sprawne poruszanie się poza wyspą wymaga innych ,przyborów".

Nowych terenów Ingrid doświadcza także poprzez zmysł równowagi. Na stałym lądzie korzysta z niego w nowy dla siebie sposób, ucząc się jazdy na rowerze, na którym następnie pokonuje niewielką część trasy swojej wyprawy: „Konieczność utrzymania równowagi przypominała tę, jakiej potrzeba na łodzi, ale powietrze to nie woda, więc Ingrid chwiała się na rowerze, a na najbardziej spadzistych zboczach musiała z niego zsiadać, podobnie jak wówczas, gdy podjazd był zbyt stromy" ${ }^{\circledR 6}$. Zmysł równowagi wydaje się przejawiać na różne sposoby w kontakcie z różnymi żywiołami, dla Ingrid była to do tej pory woda, powietrze angażuje u niej równowagę inaczej.

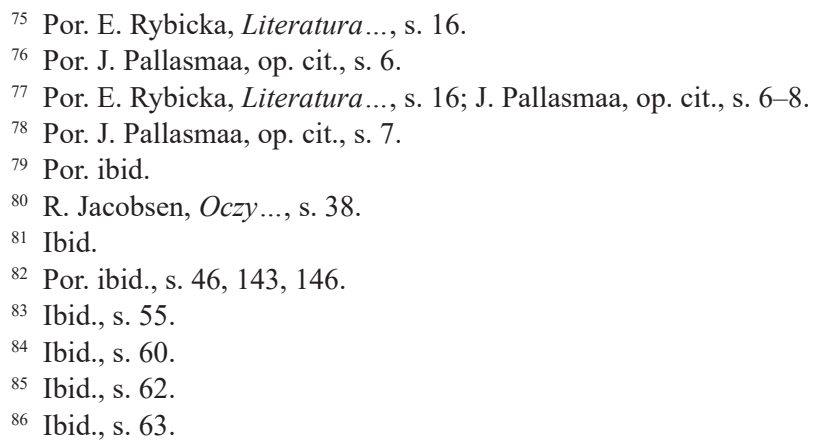


Udział konkretnych zmysłów w percepcji krajobrazu ma istotny wpływ na kształt interakcji między podmiotem i przestrzenią. I tak, dominacja wrażeń wizualnych $\mathrm{w}$ doświadczeniu otoczenia wskazuje na „odcieleśniani[e] relacji z krajobrazem" ${ }^{87}$. Inaczej rzecz ma się ze zmysłami „niższymi”. Według Magdaleny Roszczynialskiej, zapach, ,[p]odobnie jak dotyk, [...] włącza człowieka w sieć bardziej bezpośrednich relacji z otaczającymi przedmiotami, skraca dystans (no bo jak uwolnić się od zapachu?), makroperspektywę redukuje do - niekoniecznie wzrokowej - obserwacji mikrologicznej, zanurzenia w krajobrazie"88. Walter J. Ong podobnie rozumie rolę dźwięku, co opisuje w znamienny sposób:

\begin{abstract}
Wzrok wyodrębnia, dźwięk wciela. O ile wzrok sytuuje obserwatora na zewnątrz tego, co ogląda, w pewnej odległości, o tyle dźwięk wlewa się w słuchacza [...]. W danym momencie widzenie dociera do istoty ludzkiej z jednego kierunku; by spojrzeć na pokój lub na krajobraz, muszę przenieść oczy z jednego na drugi. Tymczasem kiedy słucham, otrzymuję sygnały dźwiękowe jednocześnie ze wszystkich kierunków na raz: jestem w centrum swego słyszalnego świata, który mnie spowija ${ }^{89}$.
\end{abstract}

W Oczach z Rigela w percepcji krajobrazu zwraca uwagę stosunkowo niewielka rola wrażeń wizualnych, dominują audialne i taktylne, przy znacznym udziale pozostałych. Doświadczenie krajobrazu jest zatem w bardzo dużym stopniu ucieleśnione. Manifestuje się tu konsekwencja, z jaką Jacobsen tworzy bohaterów serii. Mieszkańcy wyspy Barrøy to przede wszystkim istoty cielesne. Komentując $\mathrm{w}$ jednym $\mathrm{z}$ wywiadów mądrość swoich postaci, Jacobsen podkreśla, że „nie wyrażała się w słowach, była raczej zespojona z ich ciałami, jakby byli sportowcami”"90, czego jednym z wielu przykładów w jego cyklu jest ogólna charakterystyka bohaterów umieszczona w drugim tomie, w Białym morzu: „Barrøy jest krainą milczenia, dorośli nie tłumaczą dzieciom, co mają robić, tylko pokazują, a dzieci ich naśladują, [...] mają niewiele słów w ustach, za to dużą mądrość w rękach i nogach" "91. Pytania, dlaczego pewne czynności wykonuje się w określony sposób, są zbędne, „odpowiedź [...] nie istnieje, po prostu trzeba to robić - o tak; prawie nic nie daje się zrobić za pomocą liter"92. Akcentowaniu cielesności bohaterów towarzyszy niezwykle oszczędna narracja o ich stanach emocjonalnych. Specyficzną próbkę w Oczach z Rigela stanowi scena, w której Ingrid wreszcie poznaje losy Aleksandra. Jest to dla bohaterki bez wątpienia sytuacja ekstremalnego napięcia, jeden z najbardziej emocjonujących momentów jej życia, długo wyczekiwana chwila o decydującym znaczeniu. Targających nią emocji można się tylko domyślać, a narrator ogranicza się do opisu jej ciała. Słuchając opowieści o kochanku Ingrid „[o]parła się rękami o materac po obu

${ }^{87}$ E. Rybicka, Literatura ..., s. 16.

${ }^{88}$ M. Roszczynialska, op. cit., s. 196.

89 W.J. Ong, Oralność i piśmienność. Stowo poddane technologii, przeł. J. Japola, Lublin 1992, S. 105 .

${ }^{90}$ Roy Jacobsen: ludzie, o których piszę, byli panami mórz i dokładnie wiedzieli, co należy zrobić, stojac twarza w twarz z matkq natura, przeł. A. Tomczyk, https://kultura.onet.pl/wywiady-i-artykuly/ roy-jacobsen-ludzie-o-ktorych-pisze-byli-panami-morz-i-dokladnie-wiedzieli-co-nalezy/7rqsrp8 (dostęp: 27.04.2021).

${ }_{91}$ R. Jacobsen, Biate morze, przeł. I. Zimnicka, Poznań 2019, s. 206.

${ }^{92}$ Ibid. 
stronach ud i zacisnęła na nim palce. Zobaczyła pobielałe knykcie, poluzowała uścisk, uniosła lewą rękę, żeby zobaczyć, czy wciąż ją ma, potem znów chwyciła za materac" ${ }^{93}$. Kiedy historia dobiega końca, narrator odnotowuje, że bohaterka „[z]aczęła luzować palec po palcu, w końcu się podniosła i mogła już stać”"94.

Rzuca to interesujące światło na kwestię dalszych badań nad reprezentacją krajobrazu w Oczach z Rigela. Jak zauważa Rybicka, „ludzkie sensorium nie pozwala się odseparować od emocji” ${ }^{95}$. W powieści Jacobsena można, oczywiście, znaleźć liczne przykłady takich związków. Narrator stroni jednak najczęściej od nazywania emocji, unika wglądu do wnętrza bohaterów, opisuje w to miejsce ich ciała. $Z$ tego powodu analiza tekstu akurat $\mathrm{z}$ perspektywy geografii emocji mogłaby się okazać utrudniona. Problem ich reprezentacji i idiomatyczności ${ }^{96}$ byłby tu szczególnie aktualny.

Na koniec pozostaje jeszcze kwestia zmysłu podmiotowości. W przypadku Ingrid niezbywalnym elementem w budowaniu podmiotowości jest Barrøy. Podróż, podczas której wyspa stale kształtuje percepcję bohaterki, pozwala jej to zrozumieć. Ostatnią noc w drodze powrotnej Ingrid spędza na wyspie Hovedøya, w pokoju z widokiem na morze. Dokonuje podsumowania wędrówki, która okazuje się ważna przede wszystkim dla relacji bohaterki z rodzinnymi stronami: „[p]o tych tygodniach nie pozostał $\mathrm{w}$ niej żaden ślad, żaden odcisk stopy, lecz w oczach znów mogli jej stanąć ojciec, matka [...], i to do tego stopnia, że w uszach miała szum, kiedy siedziała na brzegu łóżka [...] i wpatrywała się w Barrøy, w jej wyraźny niebieski kontur na horyzoncie"97. Zwraca uwagę fakt, że Ingrid odbiera tu siebie wręcz w kategoriach miejsca (nienaznaczonego przez „żaden odcisk stopy”). Przemierzając wnętrze kraju śladem Aleksandra, Ingrid znajduje na nowo siebie i swoją wyspę, z którą wcześniej - o tym drugi tom serii, Białe morze - bezskutecznie próbowała zerwać więzi.

Taka relacja z miejscem pozwala opisać główną bohaterkę Oczu z Rigela koncepcją homo localis Mikołaja Madurowicza, przez którą badacz rozumie człowieka ,utożsamiającego się z miejscem i utożsamiającego miejsce jako własne dopełnienie psychofizyczne i uzupełnienie aksjologiczne, personalizującego rzeczywistość" 98 . To przez kontakt z miejscem homo localis uświadamia sobie swoje istnienie ${ }^{99}$.

Niniejszy artykuł stanowi zaledwie jedną z propozycji geopoetyckiej analizy Oczu z Rigela. Zarówno ta powieść, jak i cała seria norweskiego autora wydają się zajmującym materiałem do dalszych badań prowadzonych z tej perspektywy pogłębiających zarysowane tu rozważania, uwzględniających otwarcie na kolejne kategorie zmysłowe czy badających relacje między przestrzenią a pamięcią.

93 R. Jacobsen, Oczy..., s. 235-236.

94 Ibid., s. 238.

95 E. Rybicka, Geopoetyka..., s. 407.

96 Por. ibid., s. 268-270.

97 R. Jacobsen, Oczy..., s. 247-248.

98 M. Madurowicz, Tożsamość homo localis $w$ geografii człowieka [w:] Człowiek w badaniach geograficznych, red. W. Maik, K. Rembowska, A. Suliborski, Bydgoszcz 2006, s. 175.

99 Por. ibid. 
Wyjście poza pole badawcze geopoetyki prezentuje się równie obiecująco - tu w pierwszej kolejności na myśl przychodzi lektura somatopoetycka, ekokrytyczna czy genderowa, ale perspektywy badań z pewnością się na tym nie wyczerpują.

\section{Bibliografia (References)}

Bjørnersen M., Folk har behov for å glemme det mest pinlige, https://www.boktips. no/skjonnlitteratur/roy-jacobsen-2/ (dostęp: 27.04.2021).

Jacobsen R., Bare en mor, Oslo 2020.

Jacobsen R., Białe morze, przeł. I. Zimnicka, Poznań 2019.

Jacobsen R., De usynlige, Oslo 2013.

Jacobsen R., Hvitt hav, Oslo 2015.

Jacobsen R., Niewidzialni, przeł. I. Zimnicka, Poznań 2018.

Jacobsen R., Oczy z Rigela, przeł. I. Zimnicka, Poznań 2020.

Jacobsen R., Rigels øyne, Oslo 2017.

Konończuk E., Geobiograficzne doświadczenie lektury [w:] Przestrzenie geo(bio) graficzne w literaturze, red. E. Konończuk, E. Sidoruk, Białystok 2015, s. 63-75.

Konończuk E., Mapa jako metafora w ,opowieściach przestrzennych” Andrzeja Stasiuka [w:] Od poetyki przestrzeni do geopoetyki, red. E. Konończuk, E. Sidoruk, Białystok 2012, s. 27-48.

Madurowicz M., Tożsamość homo localis w geografii człowieka [w:] Człowiek w badaniach geograficznych, red. W. Maik, K. Rembowska, A. Suliborski, Bydgoszcz 2006, s. 169-179.

Misiak T., Audiosfera w kulturze współczesnej. Próba przybliżenia pojęcia, „Przegląd Kulturoznawczy" 2010, nr 1, s. 62-74.

Oczy z Rigela, Wydawnictwo Poznańskie, https://wydawnictwopoznanskie.pl/produkt/oczy-z-rigela/ (dostęp: 27.04.2021).

Ong W.J., Oralność i piśmienność. Słowo poddane technologii, przeł. J. Japola, Lublin 1992.

Pallasmaa J., Krajobrazy zmysłów. Dotykanie świata przez architekture, przeł. M. Choptiany, „Autoportret” 2011, nr 3, s. 4-11.

Roszczynialska M., Pótnoc - Południe. Geobiografia Michała Olszewskiego [w:] Przestrzenie geo(bio)graficzne w literaturze, red. E. Konończuk, E. Sidoruk, Białystok 2015, s. 179-202.

Roy Jacobsen: ludzie, o których piszę, byli panami mórz i dokładnie wiedzieli, co należy zrobić, stojac twarza w twarz z matka natura, przeł. A. Tomczyk, https:// kultura.onet.pl/wywiady-i-artykuly/roy-jacobsen-ludzie-o-ktorych-pisze-byli-panami-morz-i-dokladnie-wiedzieli-co-nalezy/7rqsrp8 (dostęp: 27.04.2021).

Rybicka E., Geopoetyka. Przestrzeń i miejsce we współczesnych teoriach i praktykach literackich, Kraków 2014.

Rybicka E., Literatura, geografia: wspólne terytoria [w:] Od poetyki przestrzeni do geopoetyki, red. E. Konończuk, E. Sidoruk, Białystok 2012, s. 11-25. 